Cite this: Chem. Commun., 2012, 48, 10114-10116

\title{
Fast pH-assisted functionalization of silver nanoparticles with monothiolated DNA
}

\author{
Xu Zhang ${ }^{\text {ab }}$, Mark R. Servos ${ }^{\text {b }}$, and Juewen Liu*a \\ Received 12th July 2012, Accepted 24th August 2012 \\ DOI: 10.1039/c2cc35008d
}

Attaching monothiolated DNA to silver nanoparticles has been achieved at pH 3.0 in 30 minutes and difficulties associated with DNA attachment to AgNPs at neutral pH have been revealed by studying DNA adsorption kinetics.

DNA-functionalized gold nanoparticles (AuNPs) have been extensively studied since $1996,{ }^{1}$ impacting many fields of research including biosensor development, ${ }^{2}$ materials synthesis, ${ }^{3,4}$ device fabrication, ${ }^{5}$ and drug delivery. ${ }^{6}$ In addition, many important insights into nanoscience have been gained, such as cooperative DNA melting, ${ }^{7}$ counter ion attraction, ${ }^{8}$ amplified macromolecular crowding effect, ${ }^{9}$ nanoscale curvature, ${ }^{10}$ and many distance-dependent properties. ${ }^{11}$ In contrast, the amount of work on DNAfunctionalized silver nanoparticls (AgNPs) is much less reported. Compared to AuNPs, AgNPs have a different surface plasmon peak at $\sim 400 \mathrm{~nm}$ to display yellow color with even higher extinction coefficients. AgNPs are an excellent substrate for surface enhanced Raman spectroscopy (SERS), ${ }^{12}$ and possess strong anti-microbial activities. ${ }^{13}$ Therefore, DNA-functionalized AgNPs may expand the toolbox of nanotechnology. The lack of work on AgNPs can be attributed to difficulties associated with the preparation of its DNA conjugates.

Historically, DNA-AuNP conjugates were first studied.

Attaching thiolated DNA to AuNPs is not straightforward since both carry negative charges. Addition of a high concentration of $\mathrm{NaCl}$ all at once to screen charge repulsion resulted in AuNP aggregation before a high density of DNA was attached. This problem has been elegantly solved by Mirkin and co-workers using a 'salt-aging' method, where $\mathrm{NaCl}$ was gradually added over 1-2 days. ${ }^{14}$ The same saltaging method did not work very well for AgNPs. For example, Tokareva and Hutter reported a protocol taking multiple rounds $\mathrm{NaCl}$ addition, overnight evaporation of water and dilution. ${ }^{15}$ There are other slightly modified protocols but all sharing an extremely slow salt addition requirement. ${ }^{15-18}$ Using protocols similar to AuNPs failed to generate stable conjugates as reported by Mirkin's group, who ended up coating AgNPs with a monolayer of gold to achieve DNA attachment. ${ }^{19}$ More effective attachment was realized using DNA containing multiple thiol groups to chelate the silver surface. $^{20,21}$ However, these polydentate DNAs are either commercially unavailable or very expensive. In addition, the slow salt aging procedure was still performed with the use of surfactants. ${ }^{20,22}$ Liu and co-workers tested DNA containing multiple phosphorothioate (PS) modifications. While PS DNA is much more cost-effective, a long incubation was also needed. ${ }^{23}$ Recently, it was reported that if AgNPs are very small (e.g. $\sim 2 \mathrm{~nm}$ ), thiolated DNA can be attached during their synthesis, ${ }^{24}$ but whether this method can be used for larger AgNPs remains to be tested. Based on the previous work, it appears that even monothiolated DNA can produce stable AgNP conjugates, but care has to be taken to avoid aggregation of AgNPs in the process.

We recently reported DNA attachment to citrate-capped AuNPs in just a few minutes in $\mathrm{pH} 3$ citrate buffer. ${ }^{25}$ At low $\mathrm{pH}$, the charge density on the AuNP was reduced and some of the DNA bases such as adenine and cytosine are protonated, thus significantly reducing the charge repulsion between DNA and AuNPs and among DNA strands. ${ }^{26,27}$ A low concentration of salt (e.g., $30 \mathrm{mM} \mathrm{Na}^{+}$) was still required since both AuNPs and DNA were still negatively charged even at $\mathrm{pH}$ 3. Herein, we communicate that a similar method can be applied to attach DNA to AgNPs. The reason for the difficulties associated with DNA attachment to AgNPs at neutral $\mathrm{pH}$ was also explored.

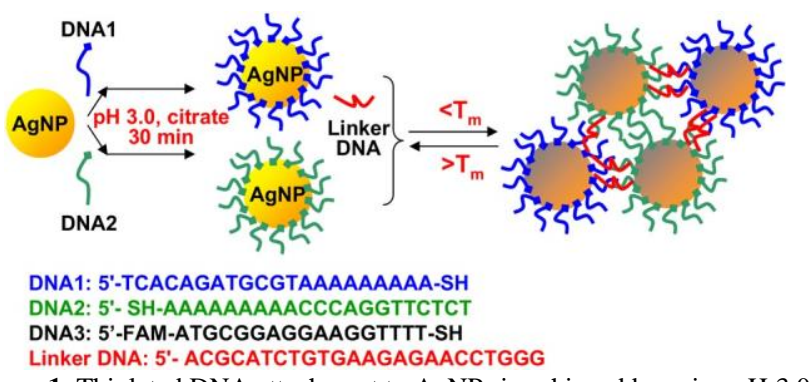

Figure 1. Thiolated DNA attachment to AgNPs is achieved by using $\mathrm{pH} 3.0$ citrate buffer with a total of $30 \mathrm{~min}$ incubation. Addition of linker DNA results in AgNP aggregation, which can be melted at elevated temperature due to DNA denaturation. Some of the DNA sequences used in this work are also shown. FAM = 6-carboxyfluorescein.

We first tested commercial AgNPs (20 nm diameter, $\sim 0.11 \mathrm{nM}$ stock concentration). A thiolated DNA with a FAM label (DNA3, see Figure 1 for sequence) was mixed with AgNPs. Direct addition of citrate $\cdot \mathrm{HCl}$ buffer ( $\mathrm{pH}$ 3.0) to a final concentration of $10 \mathrm{mM}$ caused aggregation of these AgNPs. To solve this problem, $5 \mathrm{mM}$ of the citrate $\cdot \mathrm{HCl}$ buffer was added. After $5 \mathrm{~min}$, another dose of 
$5 \mathrm{mM}$ of the same buffer was added followed by a $25 \mathrm{~min}$ incubation. This was similar the salt-aging method but was done at low $\mathrm{pH}$. The final $\mathrm{Na}^{+}$concentration was just $30 \mathrm{mM}$, much lower than the normal salt-aging performed at neutral $\mathrm{pH}$. The total operation time was siginificantly shortened to $30 \mathrm{~min}$.
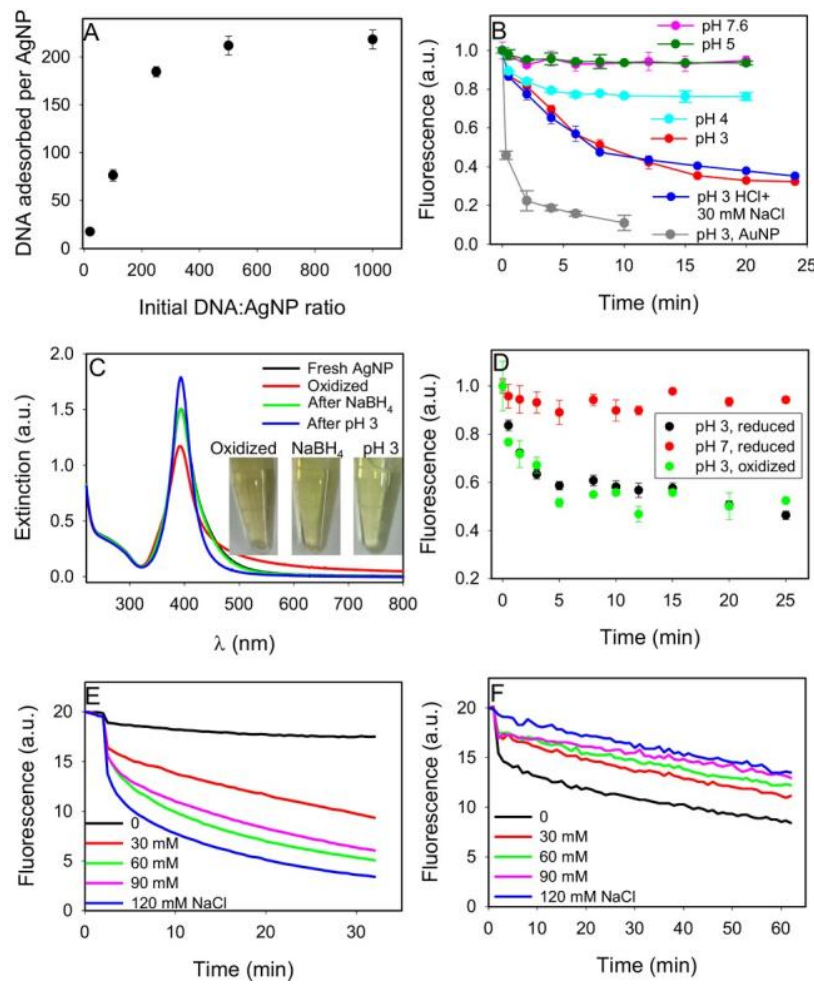

Figure 2. (A) Adsorption isotherm of DNA3 onto AgNPs. (B) Kinetics of fluorescence decrease indicating DNA adsorption onto commercial AgNPs as a function of $\mathrm{pH}$. Only the gray dots are for AuNP adsorption and the rest are for AgNP adsorption. (C) UV-vis spectra and photographs of AgNPs prepared in our lab. (D) DNA adsorption kinetics onto AgNPs prepared in our lab. Kinetics of DNA adsorption onto $20 \mathrm{~nm}$ AuNPs (E) and AgNPs (F) at $\mathrm{pH} 7.6$ with various $\mathrm{NaCl}$ concentrations.

To have a full understanding of thiolated DNA adsorption at $\mathrm{pH} 3$, adsorption isotherm was measured by incubating DNA3 with AgNPs at various ratios. Following the low $\mathrm{pH}$ incubation, the AgNPs were centrifuged to remove the free DNA and washed in $\mathrm{pH}$ 7.6 HEPES buffer $(5 \mathrm{mM})$ for four times. At this moment, only tightly adsorbed DNAs remained. KCN was then added to dissolve the AgNPs and the released DNA was quantified by fluorescence. As shown in Figure 2A, when the DNA:AgNP ratio was below $250: 1, \sim 75 \%$ of the DNAs were adsorbed. Surface saturation was reached with a loading capacity of $\sim 220$ DNA per AgNP and thus no more increase in loading was observed with even higher initial DNA concentrations. This loading capacity is comparable with that on AuNPs (e.g. 180 strands of 25 -mer DNA per $20 \mathrm{~nm}$ AuNP). ${ }^{10}$ Our higher capacity might be related to that a shorter 17-mer DNA was used. The similar DNA loading capacity suggests that the packing of DNA on AgNP and AuNP is similar, where nanoparticle surface area is likely to be the limiting factor.
The kinetics of DNA adsorption was also studied and saturated DNA adsorption was achieved in $\sim 20$ min with the $\mathrm{pH} 3$ citrate buffer (Figure 2B, red dots), which appeared slower than that with AuNPs under similar conditions (gray dots), where most DNAs were adsorbed in the first two minutes. The rate of DNA adsorption onto AgNPs was significantly reduced at higher $\mathrm{pH}$, and little adsorption was observed at $\mathrm{pH}$ higher than 5. A similarly fast adsorption rate was achieved using $\mathrm{HCl}(\mathrm{pH} 3)$ and $30 \mathrm{mM} \mathrm{NaCl}$ (Figure 2B, blue dots), indicating that citrate is not a required reagent. Similarly fast DNA adsorption and high capacity were also observed with other DNA sequences (Figure S1, ESI), showing the generality of this method.

After demonstrate fast DNA loading, we studied the stability of our DNA-AgNP conjugates. The UV-vis spectrum of unmodified AgNPs (Figure 3A, black trace) shows a sharp surface plasmon peak at $406 \mathrm{~nm}$ and a small bump at $\sim 700 \mathrm{~nm}$. Similar plasmonic features were observed for the conjugate prepared at $\mathrm{pH} 3$ and after the addition of $0.3 \mathrm{M} \mathrm{NaCl}$, indicating that the AgNPs remained fully dispersed.

Otherwise, shifted spectra would have been generated. Note that all the spectra were collected in $\mathrm{pH}$ 7.6 HEPES buffer. Therefore, only the DNA attachment step needs to be carried out at low $\mathrm{pH}$. After that, the conjugates remain stable at neutral $\mathrm{pH}$. After DNA attachment and washing, the $700 \mathrm{~nm}$ feature disappeared. Therefore, this feature is likely to be from protecting agents in the commercial AgNPs. Since the commercial AgNPs might contain stabilizing agents, to have a well-defined surface, we prepared citratecapped AgNPs following the literature procedure. ${ }^{28} \mathrm{NaBH}_{4}$ was used to reduce $\mathrm{AgNO}_{3}$ in the presence of citrate, producing a yellow color indicative the formation of AgNPs. Transimission electron microscopy (TEM) shows the size of these AgNPs to be 10-20 nm (Figure S2, ESI). However, after about $30 \mathrm{~min}$, the color of AgNPs turned to dark yellow/black, which can be converted back to yellow by adding more $\mathrm{NaBH}_{4}$ (inset of Figure 2C). The UV-vis spectra of these AgNP samples were presented in Figure 2C. Therefore, this color change was because of oxidation. Further dynamic light scattering studies also indicated that no large aggregates were formed in this oxidation process (Figure S3, ESI). We next followed the DNA adsorption kinetics using reduced AgNPs (with extra $\mathrm{NaBH}_{4}$ ) at $\mathrm{pH}$ 7, where barely any adsorption was observed (Figure 2D, red dots). Therefore, even with just weakly adsorbed citrate, DNA adsorption is still very slow at $\mathrm{pH}$ 7. Therefore, the slow DNA adsorpiton for the commercial AgNPs cannot be attributed to its stabilizing agents. Using oxidized or reduced $\mathrm{AgNP}$ at $\mathrm{pH} 3$ produced similarly faster adsorption kinetics, similar to that achieved with the commercial AgNPs. We also noticed that the color of oxidized AgNPs was changed back to yellow at $\mathrm{pH} \sim 3$ even without adding $\mathrm{NaBH}_{4}$, which was might due to the removal of the surface oxygen by the acidic buffer (inset of Figure 2C). Therefore, low $\mathrm{pH}$ for our citrate-capped $\mathrm{Ag}$ has two effects: removal of surface oxides and facilitating DNA adsorption.

Even though DNA adsorption on AgNPs was significantly accelerated at $\mathrm{pH} 3$, it was still slower than adsorption onto AuNPs under the same condition. This difference stimulated us to explore the reason for the ineffectivness of salt-aging at neutral $\mathrm{pH}$. We compared DNA adsorption kinetics onto AuNPs (Figure 2E) and 
AgNPs (Figure 2F) as a function of $\mathrm{NaCl}$ concentration at $\mathrm{pH}$ 7.6. At this $\mathrm{pH}$, we could monitor the adsorption kinetics continuously without worrying about artifacts associated with FAM quenching at low $\mathrm{pH}$. While adding $\mathrm{NaCl}$ clearly increased the rate of DNA adsorption onto AuNPs, no such acceleration (actually impeded adsorption) was observed for AgNPs. While the reason remains to be fully explored, this kinetic experiment explains the inefficiency of the salt aging method for AgNPs.
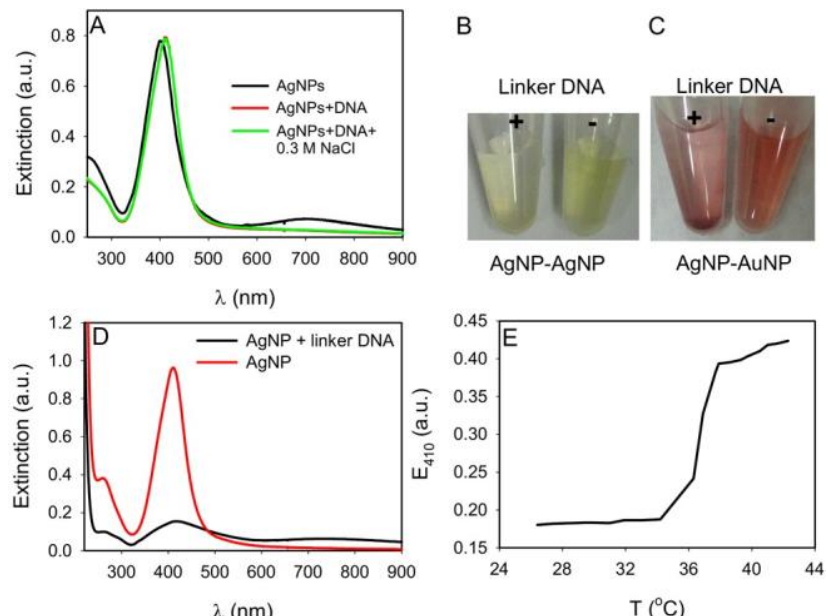

Figure 3. (A) Normalized UV-vis spectra of free AgNPs, AgNPs with attached DNA2 before and after the addition of $0.3 \mathrm{M} \mathrm{NaCl}$. (B) Photographs of mixture of AgNPs functionalized with DNA1 and DNA2 with or without linker DNA. (C) Same as (B) but DNA1 was attached to $13 \mathrm{~nm}$ AuNPs. (D) UV-vis spectra of DNA-functionalized AgNPs with or without linker DNA. (E) Melting curves of DNA-linked AgNP aggregates.

To test the function of our DNA-AgNP conjugate, we respectively prepared AgNPs attached with two types of DNA using our low $\mathrm{pH}$ method (DNA1 and DNA2, see Figure 1). Addition of linker DNA changed the color of the solution to gray/clear (Figure 3B), indicating large AgNP aggeregates were formed. The UV-vis spectrum of the aggregated sample was also shifted (Figure 3D). The melting curve of this aggregated sample was then measured, where the extinction of the surface plasmon peak at $410 \mathrm{~nm}$ was followed as a function of temperature. A sharp melting transition was observed (Figure 3E), which is one of the main features of DNAdirected assembly with multiple DNA linkages to neighboring nanoparticles. An even more obvious visual response was achieved by preparing AgNP-AuNP hybrid aggregates, where DNA1 was attached to AuNPs and DNA2 to AgNPs. Upon addition of linker DNA, purple aggregates were obtained (Figure 3C). Therefore, the DNA on AgNPs is fully functional.

In summary, we have demonstrated that monothiolated DNA can be quickly adsorbed onto AgNPs at $\mathrm{pH}$ 3. This conjugate contains a high density of DNA and is highly stable. The attached DNA molecules are functional and can recognize complementary DNA for DNA-directed assembly. The kinetics of DNA adsorption by AgNPs was slower than that by AuNPs and it cannot be accelerated by adding salt at neutral $\mathrm{pH}$, explaning the difficulty of attaching DNA to AgNPs at neutral $\mathrm{pH}$.
Funding for this work is from the University of Waterloo, the Canadian Foundation for Innovation, Canadian Institutes of Health Research, the Natural Sciences and Engineering Research Council (NSERC) of Canada and the Early Researcher Award from the Ontario Ministry of Research and Innovation.

\section{Notes and references}

Department of Chemistry, Waterloo Institute for Nanotechnology, University of Waterloo, Waterloo, Ontario, N2L 3G1, Canada. Fax: 519 7460435; Tel: 5198884567 Ext.38919; E-mail: liujw@uwaterloo.ca. Electronic Supplementary Information (ESI) available: materials and methods, TEM, DLS, additional adsorption kinetics. See DOI...

1 (a) C. A. Mirkin, R. L. Letsinger, R. C. Mucic and J. J. Storhof Nature, 1996, 382, 607; (b) A. P. Alivisatos, K. P. Johnsson, X. Peng, T. E. Wilson, C. J. Loweth, M. P. Bruchez, Jr and P. G. Schultz, Nature, 1996, 382, 609; (c) J. I. Cutler, E. Auyeung and C. A. Mirkin, J. Am. Chem. Soc., 2012, 134, 1376.

2 (a) N. L. Rosi and C. A. Mirkin, Chem. Rev., 2005, 105, 1547; (b) J. Liu, Z. Cao and Y. Lu, Chem. Rev., 2009, 109, 1948; (c) W. Zhao, M. A. Brook and Y. Li, Chembiochem, 2008, 9, 2363; (d) H. Wang, R. H. Yang, L. Yang and W. H. Tan, ACS Nano, 2009, 3, 245.

3 J. J. Storhoff and C. A. Mirkin, Chem. Rev., 1999, 99, 1849.

4 A. V. Pinheiro, D. Han, W. M. Shih and H. Yan, Nat Nano, 2011, 6, 763.

5 W. Cheng, M. J. Campolongo, J. J. Cha, S. J. Tan, C. C. Umbach, D A. Muller and D. Luo, Nat. Mater., 2009, 8, 519.

6 D. A. Giljohann, D. S. Seferos, W. L. Daniel, M. D. Massich, P. C. Patel and C. A. Mirkin, Angew. Chem. Int. Ed., 2010, 49, 3280.

7 R. Jin, G. Wu, Z. Li, C. A. Mirkin and G. C. Schatz, J. Am. Chem. Soc., 2003, 125, 1643.

8 A. K. R. Lytton-Jean and C. A. Mirkin, J. Am. Chem. Soc., 2005, 127, 12754.

9 A. Zaki, N. Dave and J. Liu, J. Am. Chem. Soc., 2012, 134, 35

10 H. D. Hill, J. E. Millstone, M. J. Banholzer and C. A. Mirkin, ACS Nano, 2009, 3, 418.

11 J. J. Storhoff, A. A. Lazarides, R. C. Mucic, C. A. Mirkin, R. L. Letsinger and G. C. Schatz, J. Am. Chem. Soc., 2000, 122, 4640.

12 H. Ko, S. Singamaneni and V. V. Tsukruk, Small, 2008, 4, 1576.

13 E. Weir, A. Lawlor, A. Whelan and F. Regan, Analyst, 2008, 133, 835 .

14 R. Elghanian, J. J. Storhoff, R. C. Mucic, R. L. Letsinger and C. A. Mirkin, Science, 1997, 277, 1078.

15 I. Tokareva and E. Hutter, J. Am. Chem. Soc., 2004, 126, 15784.

16 B. C. Vidal Jr, T. C. Deivaraj, J. Yang, H.-P. Too, G.-M. Chow, L. M. Gan and J. Y. Lee, New J. Chem., 2005, 29, 812.

17 A. Steinbruck, A. Csaki, K. Ritter, M. Leich, J. M. Kohler and W. Fritzsche, J. Biophotonics, 2008, 1, 104.

18 D. G. Thompson, K. Faulds, W. E. Smith and D. Graham, J. Phys. Chem. C, 2009, 114, 7384.

19 Y. Cao, R. Jin and C. A. Mirkin, J. Am. Chem. Soc., 2001, 123, 7961.

20 J. S. Lee, A. K. R. Lytton-Jean, S. J. Hurst and C. A. Mirkin, Nano Lett., 2007, 7, 2112.

21 J. A. Dougan, C. Karlsson, W. E. Smith and D. Graham, Nucleic Acids Res., 2007, 35, 3668.

22 S. J. Hurst, A. K. R. Lytton-Jean and C. A. Mirkin, Anal. Chem., 2006, 78, 8313

23 S. Pal, J. Sharma, H. Yan and Y. Liu, Chem. Comm., 2009, 6059

24 Y. Zheng, Y. Li and Z. Deng, Chem. Comm., 2012, 48, 6160.

25 X. Zhang, M. R. Servos and J. Liu, J. Am. Chem. Soc., 2012, 134, 7266.

26 X. Zhang, M. R. Servos and J. Liu, Langmuir, 2012, 28, 3896.

27 J. Liu, Phys. Chem. Chem. Phys., 2012, 14, 10485.

28 T. Ung, L. M. Liz-Marzan and P. Mulvaney, Langmuir, 1998, 14, 3740 . 